\title{
Analisa Perilaku Konsumen Dalam Pengambilan Keputusan Pembelian Jajanan Pasar Pada Masa Pandemi Covid-19 Di Kecamatan Delta Pawan Kabupaten Ketapang
}

\section{The Analysis of Consumer's Behaviour In The Decision Making of Traditional Snack Purchase During The Covid-19 Pandemik In Delta Pawan Sub District, Ketapang Regency}

\author{
Irianto $^{{ }^{*} \text {, Dian Fitriarni }}{ }^{1}$, dan Emi Arahman ${ }^{1}$ \\ ${ }^{1)}$ Politeknik Negeri Ketapang Program Studi Agroindustri \\ *E-mail : dira0801@gmail.com
}

\begin{abstract}
The world is currently experiencing a crisis caused by the Corona pandemic. The virus which has another name COVID-19 has also succeeded in changing people's behavior. Such as social distancing, for example, which affects changes in consumer behavior. Jajanan pasar are traditional Indonesian foods that are traded in markets, especially in traditional markets, usually made with unique tastes and attractive shapes. The purpose of this study is to determine the influence of consumer behavior factors (occupation, income, number of dependents, education level and age) in making decisions to purchase market snacks during the Covid 19 pandemic.The analytical method used is logistic regression analysis, which is one of the mathematical model approaches used to analyze the relationship of one or more independent variables with a dichotomous / binary categorical dependent variable. The results of the study explained that during the Covid pandemic 19 factors - consumer behavior factors in making decisions on buying market snacks in Delta Pawan District, Ketapang Regency, namely work, education level and age had a significant effect on consumer behavior while the income variables and the number of dependents had no significant effect. towards consumer behavior in making decisions on buying market snacks in Delta Pawan District.
\end{abstract}

Keywords: Covid 19, jajanan pasar, logistic regression

Disubmit : 11 November 2020; Diterima : 20 Desember 2020; Disetujui : 22 April 2021

\section{PENDAHULUAN}

Dunia saat ini sedang mengalami krisis yang disebabkan oleh pandemi Corona. Virus yang memiliki nama lain COVID-19 ini pun berhasil merubah perilaku masyarakat. Seperti social distancing misalnya yang mempengaruhi perubahan perilaku konsumen saat pandemi Corona. Selain prilaku konsumen wabah pandemi ini juga mempengaruhi sektor perekonomian dimana tiap sektor mengalami tumbuh negatif dikarenakan adanya pelarangan aktifitas di luar rumah. Misalnya seperti sektor parkir yang negatif sebesar $63 \%$, kemudian pusat perbelanjaan yang menurun sebesar 58\% dan toko-toko/ warung jajanan pinggir jalan yang turun sebesar 41\% (Bagus R, 2020).

Makanan adalah kebutuhan pokok setiap manusia. Dalam teori Hierarki Kebutuhan Maslow menyebutkan bahwa makanan merupakan salah satu kebutuhan fisiologis manusia. Sebagai kebutuhan dasar, makanan menjadi sangat penting bagi manusia sehingga dalam aspek bisnis pun makanan menjadi pilihan 
untuk dijadikan obyek bisnis (Jannah et al 2018). Tidak heran banyak individu yang tertarik dan menganggap bisnis kuliner sebagai jenis bisnis yang memiliki prospek yang baik, terbukti dari makin banyaknya rumah makan dan sentra kuliner diberbagai sudut kota. Selain sebagai kebutuhan dasar, kegiatan makan di luar rumah juga sudah menjadi gaya hidup masyarakat Indonesia, ditambah pula dengan meningkatnya daya beli serta pendapatan masyarakat.

Prilaku konsumen memiliki peranan penting dalam dunia pemasaran, dimana prilaku konsumen menurut Engel et al (1994) adalah suatu tindakan yang langsung terlibat dalam mendapatkan, mengkonsumsi, dan menghabiskan produk dan jasa, termasuk keputusan mendahului dan menyusuli tindakan ini. Sektor perdagangan di Kabupaten Ketapang ditahun 2018 memberikan kontribusi besar terhadap pendapatan daerah dengan presentasi sebesar 77,05\% menurut ketapang dalam angka 2019. Pada tahun 2018 juga terjadi peningkatan konsumsi kebutuhan makanan sebesar 55,25\% jauh lebih tinggi dibandingkan konsumsi non makanan yang hanya 44,75\% (BPS Ketapang 2020).

Jajanan pasar biasanya dibuat dengan cita rasa yang unik serta bentuk yang menarik. Contoh contoh jajan tradisional yang sering ditemui di Kabupaten Ketapang Khususnya Kecamatan Delta Pawan adalah kue lapis, klepon, lemper, korket, bakwan, resoles, dan lain-lain. Saat ini keberadaan jajanan tradisional lebih banyak ditemui di pasar, di tepi jalan, dan acara tertentu. Melihat kondisi saat ini dimana Kabupaten Ketapang sendiri juga merupakan daerah yang terkena dampak dari wabah COVID-19, apakah akan memberikan dampak berubahnya prilaku konsumen dalam mengambil keputusan pembelian jajanan pasar di Kecamatan Delta Pawan Kabupaten Ketapang.

\section{METODE PENELITIAN}

Pelaksanaan penelitian dilakukan di Kecamatan Delta Pawan Kabupaten Ketapang dengan batasan sebagai berikut Penentuan responden dilakukan secara Insidental sampling (teknik sampling secara kebetulan), sampling insidental ialah teknik penentuan sampel berdasarkan kebetulan, yaitu siapa saja secara incidental/kebetulan bertemu peneliti dan memenuhi syarat, sebagai responden dapat di jadikan sampel, dalam hal ini syarat responden penelitian ialah konsumen yang jajanan pasar dimana setiap anggota populasi memiliki peluang yang sama untuk dijadikan responden. Jumlah responden penelitian yaitu sebanyak 50 responden.

a. Studi Kasus pada penelitian ini adalah prilaku konsumen dalam mengambil keputusan membeli jajanan pasar di Kecamatan Delta Pawan Kabupaten Ketapang.

b. Lokasi penelitian di Kecamatan Delta Pawan Kabupaten Ketapang di lokasi penjual jajanan pasar.

c. Pengumpulan data penelitian dengan melakukan wawancara, interview, pengamatan, analisis hasil kuisioner didukung dengan data kuisioner yang kemudian diolah di Laboratorium Komputer Politekni Negeri Ketapang.

d. Waktu penelitian yang diajukan adalah 6 bulan.

Penelitian dilakukan dengan motode survey, tujuannya ialah konsumen yang membeli jajanan pasar di Kecamatan Delta Pawan Kabupaten Ketapang. Sebagian besar data yang digunakan dalam penelitian ini adalah data primer, data primer diperoleh dari survey ke konsumen yang membeli buah Jajanan pasar sebagai pengambilan keputusan untuk mengkonsumsi jajanan pasar, dengan melalui teknik wawancara dengan menggunakan daftar pertanyaan (kuisioner). Data sekunder diperoleh dari Badan Pusat statistik dan lembaga yang terkait lainnya yang berhubungan dan mendukung penelitian ini.

Analisis data yang digunakan ialah analisis analisis regresi logistik yaitu salah satu pendekatan model matematis yang digunakan untuk menganalisis hubungan satu atau beberapa variabel independen dengan sebuah variabel dependen katagori yang bersifat dikotom/binary. Model yang digunakan pada regresi logistik adalah: 


$$
\log (\mathrm{P} / 1-\mathrm{p})=\beta 0+\beta 1 \mathrm{X} 1+\beta 2 \mathrm{X} 2+\beta 3 \mathrm{X} 3+\beta 4 \mathrm{X} 4+\beta 4 \mathrm{X} 5+\alpha
$$

Dimana $\mathrm{p}$ adalah kemungkinan bahwa $\mathrm{Y}=1$, dan $\mathrm{X} 1, \mathrm{X} 2, \mathrm{X} 3, \mathrm{X} 4, \mathrm{X} 5$ adalah variabel independen, dan $\mathrm{b}$ adalah koefisien regresi

Keterangan :

$\mathrm{Y}=$ Perilaku konsumen dalam mengkonsumsi jajanan pasar (mengkonsumsi atau tidak)

$\beta 0 \ldots \beta \mathrm{k}=$ Koefisien Regresi

$\mathrm{X} 1$ = pekerjaan (bekerja /tidak)

$\mathrm{X} 2$ = Pendapatan $(\mathrm{Rp} / \mathrm{bulan})$

X3 = Jumlah Tanggungan (orang)

$\mathrm{X} 4=$ Tingkat Pendidikan

$\mathrm{X} 5=$ Usia

$\alpha=$ Error term Skala

\section{Skala Likert}

Skala likert adalah skala yang digunakan untuk mengukur sikap, pendapat, persepsi seseorang atau sekelompok orang tentang fenomena sosial. Dengan skala likert, variabel yang akan diukur dijabarkan menjadi indikator variabel. Data yang digunakan untuk mengukur tanggapan responden adalah data kuantitatif. Menggunakan sistem skor yang mempunyai bobot paling tinngi dengan poin 5 dan yang terendah mendapatkan poin 1 seperti terlihat pada Tabel 1.

Tabel 1. Skala Linkert

\begin{tabular}{lcc}
\hline Kriteria Jawaban & & Skor \\
\hline Sangat Tidak Setuju & STS & 1 \\
Tidak Setuju & TS & 2 \\
Cukup Setuju & CS & 3 \\
Setuju & S & 4 \\
Sangat Setuju & SS & 5 \\
\hline
\end{tabular}

Sumber : Data diolah, 2020

\section{HASIL DAN PEMBAHASAN}

Secara geografis Kabupaten Ketapang merupakan salah satu kabupaten yang berada di Provinsi Kalimantan Barat, terletak di antara garis $0^{\circ} 19^{\prime} 00^{\prime \prime}-3^{\circ} 05^{\prime}$ 00” Lintang Selatan dan $108^{\circ} 42^{\prime} 00^{\prime \prime}-111^{\circ} 16^{\prime}$ 00" Bujur Timur. Berdasarkan hasil proyeksi penduduk tahun 2018 jumlah penduduk Kabupaten Ketapang diprediksi sebanyak 504.008 jiwa (260.789 jiwa berjenis kelamin laki-laki dan 243.219 jiwa berjenis kelamin perempuan). Kecamatan dengan tingkat kepadatan penduduk terpadat adalah Kecamatan Delta Pawan yaitu sekitar1.292 jiwa per Km2, sedangkan kecamatan dengan tingkat kepadatan penduduk terjarang adalah Kecamatan Hulu Sungai, yaitu setiap Km2 dihuni oleh sekitar 3 jiwa.

Persentase pencari kerja yang terdaftar di Dinas Sosial, Tenaga Kerja, dan Transmigrasi pada tahun 2018 didominasi oleh pencari kerja berjenis kelamin laki-laki, yaitu sekitar 57,88 persen sedangkan sisanya sekitar 42,12persen jenis kelamin perempuan. Pada Tahun 2018, menurut latar belakang pendidikan para pencari kerja, tercatat pencari kerja dengan ijazah SMA adalah yang tebanyak yaitu sekitar 48,95 persen.

Unit usaha baik skala besar, menengah dan kecil di Kabupaten Ketapang mengalami kenaikan dari tahun 2017 sebanyak 771 unit usaha menjadi 809 unit usaha pada tahun 2018. Hal ini menjadi sebuah penanda berkembangnya sektor industri di Kabupaten Ketapang. Dengan unit usaha terbanyak terdapat pada Kecamatan Delta Pawan sebesar 423 unit usaha

Pengeluaran rata-rata per Kapita per bulan penduduk Kabupaten Ketapang pada tahun 2018 sebanyak Rp 1.039.150. Pengeluaran tersebut sekitar 14,47 persen lebih tinggi dibandingkan dengan tahun sebelumnya. Persentase pengeluaran penduduk untuk konsumsi makanan utamanya adalah makanan dan 
minuman jadi yaitu sekitar 24,18 persen, padi-padian sebesar 14,30 persen, tembakau sekitar 14.23 persen, dan ikan sekitar 14.22 persen. Sedangkan untuk komoditi lainnya angkanya kurang dari 10,00 persen. Pengeluaran penduduk untuk konsumsi non makanan didominasi oleh pengeluaran perumahan dan fasilitas rumah tangga yaitu sekitar 59,66 persen, diikuti oleh pengeluaran barang dan jasa sekitar 21.45 persen

\section{Karakteristik Responden}

Responden pada penelitian ini adalah masyarakat yang membeli Jajanan Pasar di Kecamatan Delta Pawan yang merupakan salah satu Kecamatan yang berada ditengah kota Ketapang dimana banyak penjual jajanan pasar disetiap pinggir jalannya. responden yang mengkonsumsi Jajanan pasar di klasifikasikan berdasarkan: Pekerjaan, pendapatan, jumlah tanggungan dan tingkat pendidikan, dan Usia.

Tabel 1. Karakteristik responden jajanan pasar terhadap pekerjaan

\begin{tabular}{cccc}
\hline No & Pekerjaan & Jumlah Orang & Persentase \\
\hline 1 & Karyawan Swasta & 17 & $34,00 \%$ \\
2 & PNS & 17 & $34,00 \%$ \\
3 & Wirausaha & 16 & $32,00 \%$ \\
Jumlah & & 50 & \\
\hline
\end{tabular}

Sumber : Data diolah, 2020

Pekerjaan akan mempengaruhi besar kecilnya daya beli dari seorang konsumen. Dimana seorang yang memiliki pekerjaan, tentunya orang tersebut akan memiliki kemampuan untuk membeli beraneka ragam kebutuhannya, begitu pun sebaliknya. Data responden jajanan pasar berdasarkan pendapatannya terlihat dalam Tabel 1. Tabel 1 menunjukkan data mengenai pekerjaan responden jajanan pasar, dimana jumlah responden yang bekerja sebagai karyawan swasta sebanyak 17 orang (34,00\%), responden yang bekerja sebagai Pegawai Negeri Sipil (PNS) sebanyak 17 orang $(34,00 \%)$, responden yang bekerja sebagai wirausaha sebanyak 16 orang (32\%). Berdasarkan tabel diatas, jenis pekerjaan konsumen akan menjadi pertimbangan dalam proses pengambilan keputusan pembelian dan pola konsumsi, sehingga mempengaruhi daya beli konsumen terhadap jajanan pasar.

Tabel 2. Karakteristik responden jajanan pasar terhadap pendapatan

\begin{tabular}{cccc}
\hline No & Pendapatan & $\begin{array}{c}\text { Jumlah } \\
\text { Orang }\end{array}$ & Persentase \\
\hline 2 & Antara Rp 0 - Rp 3.000.000 & 30 & $60,00 \%$ \\
3 & Di atas Rp. 3.000.000 & 20 & $40,00 \%$ \\
Jumlah & & 50 & \\
\hline
\end{tabular}

Sumber : Data diolah, 2020

Jumlah pendapatan akan mempengaruhi besar kecilnya daya beli dari seorang konsumen. Semakin besar pendapatan seseorang, semakin besar pula kemampuan seseorang dalam membeli beraneka ragam kebutuhannya, begitu pun sebaliknya (Zukryandry et al 2019). Data responden jajanan pasar berdasarkan pendapatannya terlihat dalam Tabel 2. Tabel 2 menunjukkan data mengenai pendapatan responden buah jeruk impor, dimana jumlah responden yang memiliki pendapatan $\mathrm{Rp} 0$ - Rp 3.000 .000 sebanyak 30 orang (60\%), responden yang memiliki pendapatan diatas Rp. 3.000 .000 sebanyak 20 orang (40\%). Berdasarkan tabel diatas, besarnya pendapatan konsumen akan menjadi pertimbangan dalam proses pengambilan keputusan pembelian dan pola konsumsi, sehingga mempengaruhi daya beli konsumen terhadap jajanan pasar. 
Irianto dkk : Analisa Perilaku Konsumen Dalam Pengambilan Keputusan Pembelian Jajanan

Tabel 3. Karakteristik responden jajanan pasar terhadap jumlah tanggungan

\begin{tabular}{cccc}
\hline No & Jumlah Tanggungan & $\begin{array}{c}\text { Banyak } \\
\text { Orang }\end{array}$ & Persentase \\
\hline 1 & & 25 & $50,00 \%$ \\
2 & $1-2$ orang & 25 & $50,00 \%$ \\
Jumlah & Diatas 3 orang & 50 & \\
\hline
\end{tabular}

Sumber : Data diolah, 2020

Keluarga adalah lingkungan yang paling dekat konsumen. Anggota keluarga akan mempengaruhi konsumen dalam pengambilan keputusan pembelian jajanan pasar (Sutarni et al 2018). Data jumlah tanggungan keluarga responden jajanan pasar terlihat pada Tabel 3. Tabel 3 menunjukkan bahwa sebagian besar responden jajanan pasar pada jumlah tangungan $1-2$ orang dan diatas 3 orang dengan presentasi nilai masing - masing sebesar 50\%. Semakin besar jumlah tanggungan keluarga dalam satu rumah tangga maka semakin besar pula jumlah kebutuhan akan pangan khususnya jajanan pasar dan akan mempengaruhi konsumen dalam melakukan pembelian jajanan pasar.

Tabel 4. Karakteristik responden jajanan pasar terhadap tingkat pendidikan

\begin{tabular}{cccc}
\hline No & Tingkat Pendidikan & Jumlah Orang & Persentase \\
\hline 1 & SD-SMA & 25 & $50,00 \%$ \\
2 & DIII-S2 & 25 & $50,00 \%$ \\
Jumlah & & 50 & \\
\hline
\end{tabular}

Sumber : Data diolah, 2020

Konsumen yang memiliki pendidikan yang tinggi yang lebih baik akan sangat responsif terhadap informasi dan selektif dalam memilih produk, selain itu pendidikan juga berperan dalam memiliki pengetahuan tentang gizi dalam suatu produk. Tabel 4 menunjukkan bahwa responden jajanan pasar memiliki tingkat pendidikan yang tinggi, dapat dilihat responden buah jajanan pasar yang memiliki tingkat pendidikan terbesar yaitu SD - SMA dengan nilai persentase sebesar $50 \%$ dan tingkat pendidikan D3 - S2 memiliki nilai presentase sebesar $50 \%$. Semakin tinggi tingkat pendidikan tentunya akan mempengaruhi keinginan seseorang untuk melakukan pembelian jajanan pasar biasanya konsumen ini akan lebih selektif dalam membeli jajanan pasar.

Tabel 5. Karakteristik responden jajanan pasar terhadap usia

\begin{tabular}{cccc}
\hline No & Usia & $\begin{array}{c}\text { Jumlah } \\
\text { Orang }\end{array}$ & Persentase \\
\hline 1 & $1.16-35$ tahun & 25 & $50,00 \%$ \\
\hline 2 & $2.36-55$ tahun & 25 & $50,00 \%$ \\
\hline Jumlah & & 50 & \\
\hline
\end{tabular}

Sumber : Data diolah, 2020

Usia responden pada penelitian adalah berkisar antara 16 hingga diatas 55 tahun. Hal tersebut menunjukkan keadaan responden yang mengkonsumsi jajanan pasar masih aktif dalam mempertimbangkan atribut-atribut jajanan pasar yang akan dikonsumsi. Data responden yang diperoleh menunjukkan jumlah konsumen yang seimbangbaik usia 16 -35 tahun maupun 36 -55 tahun. Data kelompok umur konsumen jajanan pasar yang terlihat pada Tabel 5, konsumen dengan umur 16 -35 tahun berjumlah 25 orang (50\%) dan konsumen dengan usia $36-55$ tahun juga berjumlah 25 orang ( $50 \%$ ). Usia sendiri memiliki pengaruh tersendiri pada konsumen dalam membeli jajanan pasar.

\section{Faktor-faktor yang Memengaruhi Perilaku Konsumen Dalam Mengkonsumsi Jajanan Pasar .}

Faktor-faktor yang mempengaruhi perilaku konsumen dalam mengkonsumsi jajanan pasar di Kabupaten Ketapang Kecamatan Delta Pawan dianalisis dengan menggunakan regresi logistik yang 
pengolahan datanya menggunakan software SPSS 16. Analisis dilakukan secara bertahap untuk mendapatkan persamaan dugaan yang baik sesuai kaidah ekonometrika, dengan variabel terikatnya (dependent variabel) adalah perilaku konsumen(Y) dan variabel bebas (independent variabel) terdiri dari Pekerjaan (X1), pendapatan (X2), tanggungan keluarga (X3), tingkat pendidikan (X4) dan Usia (X5) Hasil regresi faktorfaktor yang memengaruhi perilaku konsumen dalam mengkonsumsi jajanan pasar di Kabupaten Ketapang dengan menggunakan aplikasi software SPSS 16.

Tabel 6. Klasifikasi Pengambilan Keputusan

\begin{tabular}{lccccr} 
& & & \multicolumn{3}{c}{ Predicted } \\
\cline { 3 - 5 } & & Observed & \multicolumn{2}{c}{ Hasil Keputusan } & \multicolumn{2}{c}{ Percentage } \\
\cline { 3 - 5 } Step 0 & Hasil Keputusan & Tidak membeli & 0 & 21 & .0 \\
& & Membeli & 0 & 29 & 100.0 \\
& Overall Percentage & & & & 82.5 \\
\hline
\end{tabular}

Sumber : Data diolah, 2020

Klasifikasi dapat dijelaskan terkait pengambilan keputusan pembelian jajanan pasar jika dikaitkan dengan faktor pendapatan, pekerjaan, jumlah tanggungan, tingkat pendidikan dan usia (Ritonga, 2017). Dari 50 responden yang melakukan pengisian kuisioner terdapat 21 orang yang tidak melakukan pembelian jajanan pasar dimasa pandemi covid 19, dan 29 orang lainya tetap melakukan pembelian jajanan pasar dimana pandemi covid tidak mempengaruhi responden dalam mengambil keputusan pembelian jajanan pasar dengan nilai persentasi harapan $58 \%$.

Tabel 7. Model prediksi nilai observasi

\begin{tabular}{lccc}
\hline Step & -2 Log Likelihood & Cox \& Snell R Square & Nagelkerke R Square \\
\hline 1 & $51.676^{\mathrm{a}}$ & .279 & .375 \\
\hline
\end{tabular}

Sumber : Data diolah, 2020

Nilai signifikansi sebesar 0,375 > 0,05 menunjukkan bahwa tidak ada perbedaan antara model dengan nilai observasinya, sehingga model mampu memprediksi nilai observasi tersebut, atau dengan kata lain, model dapat diterima karena mampu memprediksikan pengaruh variabel-variabel independen terhadap variabel dependen.

Tabel 8. Tabel penjelasan variabelitas variabel

\begin{tabular}{lccl}
\hline Step & Chi-square & Df & Sig. \\
\hline 1 & 1.115 & 7 & .993
\end{tabular}

Sumber : Data diolah, 2020

Model Sumary Nagelkerke R Square pada tabel di atas menunjukkan nilai sebesar 0,993 atau 99\%. Hal ini berarti, variabilitas variabel dependen dapat dijelaskan oleh variabilitas variabel-variabel independen sebesar 99\%. Artinya, seluruh variabel independen mempengaruhi variabel dependen secara serentak pada kisaran 99\%, sedangkan $1 \%$ dipengaruhi atau dijelaskan oleh variabel variabel yang tidak dimasukkan dalam penelitian ini.

\section{Signifikan dan Koefisien Regresi}

Signifikansi (Sig.) pada tabel menunjukkan pengaruh masing-masing variabel independen (secara parsial) terhadap variabel dependen. Penelitian ini menggunakan tingkat signifikansi $10 \%$, sehingga suatu variabel independen dianggap memiliki pengaruh yang signifikan apabila nilai signifikansinya (Sig.) lebih kecil daripada 0,1. Meski demikian,. Berikut ini adalah signifikansi untuk masing-masing variabel independen beserta koefisien regresi (nilai $\beta$ dalam tabel), dilengkapi dengan interpretasi yang disajikan untuk menjawab rumusan masalah . 
Irianto dkk: Analisa Perilaku Konsumen Dalam Pengambilan Keputusan Pembelian Jajanan

Tabel 9. Tabel Koefisien dan Signifikasi Regresi

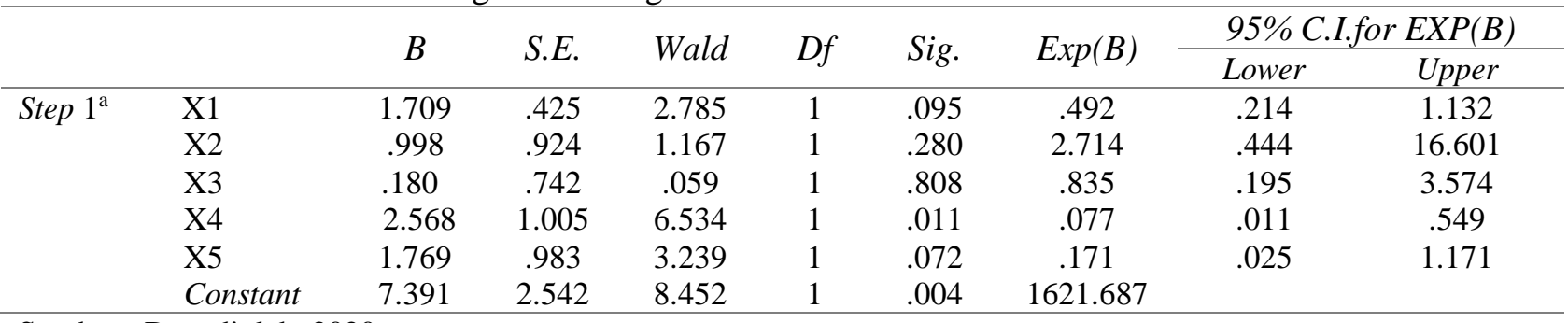

Sumber : Data diolah, 2020

\section{Pengaruh Pekerjaan Variabel X1}

Tingkat signifikansi 0,097 lebih kecil dari pada 0,1 (tingkat kesalahan 10\%) yang dapat diinterpretasikan bahwa terdapat pengaruh yang signifikan antara pekerjaan dengan perilaku konsumen. Koefisien regresi sebesar 1,709 menujukan bahwa pekerjaan memengaruhi perilaku konsumen dalam melakukan pembelian jajanan pasar dimasa pandemi Covid 19 dengan probabilitas 1 (100\%) . Dalam hal ini pekerjaan mempengaruhi konsumen dalam membeli jajanan pasar karena banyak konsumen yang bekerja pada sektor swasta dan wirausaha, dimana pada masa pandemi covid 19 mempengaruhi bidang pekerjaan tersebut sehingga membuat konsumen lebih menahan pengeluaran untuk konsumsi.

\section{Pengaruh variabel Pendapatan X2}

Tingkat signifikansi 0,280 lebih besar dari pada 0,1 (tingkat kesalahan 10\%) yang dapat diinterpretasikan bahwa tidak terdapat pengaruh yang signifikan antara pendapatan dengan perilaku konsumen. Koefisien regresi sebesar 0,998 menujukan bahwa pendapatan tidak memengaruhi perilaku konsumen dalam melakukan pembelian jajanan pasar dimasa pandemi Covid 19 dengan probabilitas 1 $(100 \%)$. Dalam hal ini pendapatan konsumen tidak mempengaruhi konsumen dalam membeli jajanan pasar karena dari segi harga jajanan pasar sangat terjangkau sehingga konsumen tetap melakukan pembelian jajanan pasar walaupun pembelian dalam jumlah yang sedikit.

\section{Pengaruh variabel Jumlah Tanggungan X3}

Tingkat signifikansi 0,808 lebih kecil dari pada 0,1 (tingkat kesalahan 10\%) yang dapat diinterpretasikan bahwa tidak terdapat pengaruh yang signifikan antara jumlah tanggungan dengan perilaku konsumen. Koefisien regresi sebesar 0,180 menujukan bahwa jumlah tanggungan tidak memengaruhi perilaku konsumen dalam melakukan pembelian jajanan pasar dimasa pandemi Covid 19 dengan probabilitas $1(100 \%)$. Dalam hal ini jumlah tanggungan konsumen tidak mempengaruhi konsumen dalam membeli jajanan pasar karena dari segi harga jajanan pasar sangat terjangkau sehingga konsumen tetap melakukan pembelian jajanan pasara walaupun pembelian dalam jumlah yang sedikit dan juga konsumen melakukan pembelian karena kebutuhan dimana jajanan pasar ini sendiri terkadang menjadi menu sarapan para konsumen (Yuliati, 2013).

\section{Pengaruh variabel Tingkat Pendidikan X4}

Tingkat signifikansi 0,011 lebih besar dari pada 0,1 (tingkat kesalahan 10\%) yang dapat diinterpretasikan bahwa terdapat pengaruh yang signifikan antara tingkat pendidikan dengan perilaku konsumen dalam melakukan pembelian jajanan pasar dimasa pandemi Covid 19. Koefisien regresi sebesar 2,568 menujukan bahwa tingkat pendidikan memengaruhi perilaku konsumen dalam melakukan pembelian jajanan pasar dimasa pandemi Covid 19 dengan probabilitas 1 (100\%). Dalam hal ini tingkat pendidikan konsumen mempengaruhi konsumen dalam membeli jajanan pasar karena konsumen pada masa pandemi covid 19 lebih memilih jajanan yang bersih, bergizi dan dikemas dengan rapi sehingga terhindar dari kontak dengan konsumen yang lain. 


\section{Pengaruh variabel Usia X5}

Tingkat signifikansi 0,072 lebih besar dari pada 0,1 (tingkat kesalahan 10\%) yang dapat diinterpretasikan bahwa terdapat pengaruh yang signifikan antara usia dengan perilaku konsumen. Koefisien regresi sebesar 1,769 menujukan bahwa usia memengaruhi perilaku konsumen dalam melakukan pembelian jajanan pasar dimasa pandemi Covid 19 dengan probabilitas 1 (100\%). Dalam hal ini usia konsumen mempengaruhi konsumen dalam membeli jajanan pasar karena jenis jajanan pasar yang cukup banyak dimana konsumen yang memiliki usia diatas 35 tahun lebih selektif melakukan pembelian jajanan pasar yang memiliki komposisi tertentu yaitu tidak digoreng (tidak ada minyak) dan jajanan yang sedikit gula, dan juga dimasa pandemi covid 19 banyak konsumen dengan usia tersebut lebih memilih jajanan dengan kemasan yang baik.

\section{KESIMPULAN}

Berdasarkan hasil dan pembahasan dapat dijelaskan bahwa pada masa pandemi Covid 19 faktor faktor perilaku konsumen dalam pengambilan keputusan pembelian jajanan pasar di Kecamatan Delta Pawan Kabupaten Ketapang yaitu pekerjaan, tingkat pendididikan dan usia memberikan pengaruh yang nyata, sedangkan pendapatan dan jumlah tanggungan tidak memberikan pengaruh yang nyata terhadap perilaku konsumen dalam pengambilan keputusan pembelian jajanan pasar di Kecamatan Delta Pawan. Dijelaskan juga pada perhitungan klasifikasi pengambilan keputusan bahwa dari 50 orang responden sebanyak 21 orang yang tidak melakukan pembelian jajanan pasar dan 29 orang tetap melakukan pembelian jajanan pasar dimasa pandemi covid 19 dengan nilai persentasi harapan sebesar $58 \%$. Hasil perhitungan $\mathrm{R}^{2}$ atau Nagelkerke R Square yang menjelaskan bahwa variabel perilaku konsumen pembelian jajanan pasar di Kecamatan Delta Pawan dipengaruhi oleh pekerjaan, pendapatan, jumlah tanggungan, tingkat pendididikan dan usia sebesar 0,993 atau 99\%. Hal ini berarti, variabilitas variabel dependen dapat dijelaskan oleh variabilitas variabel-variabel independen sebesar 99\%. Artinya, seluruh variabel independen mempengaruhi variabel dependen secara serentak pada kisaran 99\%, sedangkan $1 \%$ dipengaruhi atau dijelaskan oleh variabel variabel yang tidak dimasukkan dalam penelitian ini.

\section{SARAN}

Saran yang dapat diberikan pada penelitian ini yaitu jajanan pasar yang dijual di pinggir jalan diharapkan lebih memperhatikan kemasan jajanan, karena banyak jajanan yang dijual masih dalam bentuk tidak berkemasan, dimana pada masa pandemi covid 19 saat ini konsumen sangat memperhatikan kondisi fisik jajanan dan menjadi lebih selektif yang tentunya akan mempengaruhi jumlah penjualan jajanan itu sendiri.

\section{DAFTAR PUSTAKA}

Bagus R. (2020). Dampak Pedemi Covid 19 Pada Berbagai Sektor Bisnis.

BPS [Badan Pusat Statistik]. (2020). Kabupaten Ketapang Dalam Angka 2020. Ketapang.

Engel, J. F., R. D. Bladiwell., dan P., \& Miniard. (1994). Perilaku Konsumen Jilid 1. Jakarta: Bina rupa Aksara.

Jannah, N., Antara, M., \& Effendy. (2018). Faktor-Faktor Yang Memengaruhi Perilaku Konsumen dalam Mengkonsumsi Buah Jeruk Impor Di Kota Palu. Agroland, 25(2), 121-129.

Ritonga, Z. (2017). Faktor-Faktor Yang Mempengaruhi Konsumen Dalam Pembelian Makanan Jajanan Tradisional Di Kelurahan Perdamean. Jurnal Ecobisma, 4(2), 951-952. 
Irianto dkk: Analisa Perilaku Konsumen Dalam Pengambilan Keputusan Pembelian Jajanan

Sutarni, Irawati, L., Unteawati, B., \& Yolandika, C. (2018). Proses Pengambilan Keputusan. Journal of Food System and Agribusiness, 2(1), 17-24. https://doi.org/10.31227/osf.io/4byj6

Yuliati, U. (2013). Faktor -Faktor Yang Mempengaruhi Konsumen Dalam Pembelian Makanan Jajan Tradisional Di Kota Malang. Manajemen Bisnis, 1(1), 7. https://doi.org/10.22219/jmb.v1i1.1318

Zukryandry, Hidayat, B., \& Berliana, D. (2019). Analisis preferensi konsumen dan proksimat cookies bebas gluten berbahan baku tepung ubi kayu ( manihot utilissima ) tinggi protein. Journal of Food System and Agribusiness, 3(2), 63-71. 